University of Nebraska - Lincoln

DigitalCommons@University of Nebraska - Lincoln

Faculty Papers and Publications in Animal

Science

Animal Science Department

January 2001

\title{
Genetic correlations for litter weight weaned with growth, prolificacy, and wool traits in Columbia, Polypay, Rambouillet, and Targhee sheep
}

\author{
L. Dale Van Vleck \\ University of Nebraska-Lincoln, dvan-vleck1@unl.edu \\ C. M. Bromley \\ University of Nebraska-Lincoln \\ G. D. Snowder \\ USDA, ARS, U.S. Sheep Experimental Station, Dubois, ID
}

Follow this and additional works at: https://digitalcommons.unl.edu/animalscifacpub

Part of the Animal Sciences Commons

Van Vleck, L. Dale; Bromley, C. M.; and Snowder, G. D., "Genetic correlations for litter weight weaned with growth, prolificacy, and wool traits in Columbia, Polypay, Rambouillet, and Targhee sheep" (2001). Faculty Papers and Publications in Animal Science. 221.

https://digitalcommons.unl.edu/animalscifacpub/221

This Article is brought to you for free and open access by the Animal Science Department at DigitalCommons@University of Nebraska - Lincoln. It has been accepted for inclusion in Faculty Papers and Publications in Animal Science by an authorized administrator of DigitalCommons@University of Nebraska - Lincoln. 


\title{
Genetic correlations for litter weight weaned with growth, prolificacy, and wool traits in Columbia, Polypay, Rambouillet, and Targhee sheep ${ }^{1}$
}

\author{
C. M. Bromley ${ }^{*, 2}$, L. D. Van Vleck $\dagger^{, 3}$, and G. D. Snowder \\ *Department of Animal Science, University of Nebraska, Lincoln 68583-0908; \\ †USDA, ARS, Roman L. Hruska U.S. Meat Animal Research Center, Lincoln, NE 68583-0908; and \\ $\ddagger$ USDA, ARS, U.S. Sheep Experimental Station, Dubois, ID 83423
}

\begin{abstract}
Total litter weight weaned at $120 \mathrm{~d}$ postpartum per ewe lambing is often believed to be a measure of range ewe productivity. Genetic correlations for litter weight weaned at $120 \mathrm{~d}$ with prolificacy, growth, and wool traits for Columbia, Polypay, Rambouillet, and Targhee sheep were estimated using REML with animal models. Observations per breed ranged from 5,140 to 7,083 for litter weight weaned, from 5,140 to 7,095 for prolificacy traits, from 7,750 to 9,530 for growth traits, and from 4,603 to 18,443 for wool traits. Heritability estimates for litter weight weaned were low and ranged from 0.02 to 0.11 . Fraction of variance due to permanent environmental effects av-
\end{abstract}

eraged 0.05 and, due to effects of mates, averaged 0.01 . Estimates of genetic correlations with litter weight weaned varied from breed to breed. The ranges were as follows: 0.42 to 0.65 with litter size born, 0.80 to 0.99 with litter size weaned, -0.22 to 0.28 with birth weight, -0.07 to 0.23 with average daily gain to weaning, -0.56 to 0.19 with fleece weight, -0.15 to 0.02 with fleece grade, and -0.11 to 0.08 with staple length. Results suggest that, if selection were practiced on litter weight weaned, the average correlated responses would be expected to be favorable or neutral for prolificacy, growth, and wool traits although responses might vary from breed to breed.

Key Words: Growth, Heritability, Selection, Wool

(C2001 American Society of Animal Science. All rights reserved.

J. Anim. Sci. 2001. 79:339-346

\section{Introduction}

Total litter weight weaned per ewe lambing is a trait often used as an overall measure of range lamb production. Ercanbrack and Knight (1998) reported favorable genetic and economic responses to selection for litter weight weaned. However, before litter weight weaned can be proposed as a selection trait, the phenotypic and genetic relationships with other production traits need to be determined. Estimates of genetic correlations between litter weight weaned and prolificacy, growth, or wool traits have not been reported, but signs for these correlations have been inferred by Ercanbrack and Knight (1998). These correlations and other genetic and phenotypic (co)variances are needed to calculate expected correlated responses in growth, prolificacy, and

\footnotetext{
${ }^{1}$ Published as paper no. 12957, Journal Ser., Nebraska Agric. Res. Div., Univ. of Nebraska, Lincoln 68583-0908.

${ }^{2}$ Current address: Genetic Epidemiology Branch, NCI, 6130 Executive Boulevard, Bethesda, MD 20852.

${ }^{3}$ Correspondence: A218 Animal Sciences (phone: 402/472-6010; fax: 402/472-6362; E-mail: dvan-vleck1@unl.edu).

Received March 13, 2000.

Accepted September 1, 2000.
}

wool traits if selection is based on litter weight weaned and also for multiple-trait genetic evaluations involving litter weight weaned. Previous studies of correlations with litter weight weaned are few (e.g., Fogarty, 1995). The objectives of this study were to estimate genetic parameters for the composite trait of litter weight weaned and to estimate genetic correlations between litter weight weaned and growth, prolificacy, and wool traits for dual purpose breeds of sheep raised under range conditions.

\section{Materials and Methods}

\section{Data}

Data were for the period 1974 to 1996 from animals of Columbia, Polypay, Rambouillet, and Targhee breeds measured at the United States Sheep Experiment Station, Dubois, ID. Summaries of the number of animals with records per breed and type of trait are shown in Table 1. Means and unadjusted standard deviations for each trait by breed are shown in Table 2. Ercanbrack and Knight (1998) have described general management of these flocks. Most ewes were bred in pens for $21 \mathrm{~d}$ with single-sire matings. Ewes grazed winter ranges until weather required moving to a feedlot, where a 
Table 1. Summary of numbers of records, sires, and dams for litter weight weaned and for prolificacy, weight, and wool traits by breed

\begin{tabular}{|c|c|c|c|c|}
\hline \multirow[b]{2}{*}{ Trait/number } & \multicolumn{4}{|c|}{ Breed } \\
\hline & Columbia & Polypay & Rambouillet & Targhee \\
\hline \multicolumn{5}{|l|}{ Litter weight weaned } \\
\hline Records & 5,140 & 7,083 & 5,695 & 6,452 \\
\hline Ewes & 1,941 & 3,258 & 2,268 & 2,402 \\
\hline Sires of ewes & 241 & 499 & 418 & 453 \\
\hline Dams of ewes & 1,129 & 1,952 & 1,337 & 1,382 \\
\hline Mating sires & 242 & 298 & 404 & 457 \\
\hline \multicolumn{5}{|l|}{ Prolificacy } \\
\hline Records & 5,140 & 7,095 & 5,695 & 6,452 \\
\hline Ewes & 1,941 & 3,261 & 2,268 & 2,402 \\
\hline Sires of ewes & 241 & 500 & 418 & 453 \\
\hline Dams of ewes & 1,129 & 1,953 & 1,337 & 1,382 \\
\hline \multicolumn{5}{|c|}{ Birth weight/gain to weaning } \\
\hline Records (animals) & 7,750 & 9,524 & 9,530 & 9,321 \\
\hline Sires of animals & 263 & 246 & 451 & 492 \\
\hline Dams of animals & 2,095 & 2,285 & 2,285 & 2,577 \\
\hline \multicolumn{5}{|l|}{ Fleece weight/grade } \\
\hline Records & 11,673 & 9,324 & 18,443 & 15,014 \\
\hline Animals with records & 4,239 & 3,615 & 6,434 & 5,459 \\
\hline Sires of animals & 286 & 234 & 559 & 536 \\
\hline Dams of animals & 1,709 & 1,394 & 2,390 & 2,203 \\
\hline \multicolumn{5}{|l|}{ Staple length } \\
\hline Records & 4,603 & 3,529 & 7,030 & 5,534 \\
\hline Animals with records & 3,271 & 2,790 & 5,475 & 4,435 \\
\hline Sires of animals & 276 & 209 & 531 & 511 \\
\hline Dams of animals & 1,406 & 1,117 & 2,110 & 1,855 \\
\hline
\end{tabular}

late-gestation ration was fed to condition them for lambing. Ewe lambs were bred at 7 mo of age to lamb as yearlings. Yearlings with lambs were managed with mature ewes as part of a range band. The ewes were lambed in sheds at Dubois during April and May. During late spring and summer, ewes with lambs were herded in one of two or three bands of flocks grazing on high-elevation $(2,590 \mathrm{~m})$ mountain conifer ranges. Lambs were weaned, as is the standard management practice in western intermountain ranges, in early September at approximately $120 \mathrm{~d}$ of age and then grazed on pastures or fields for a few weeks before moving them to a feedlot. In the fall, ewes were grazed on sagebrush grasslands $(1,700 \mathrm{~m})$ until breeding. Rams were grazed in summer on high meadow pasture and wintered in a feedlot.

Prolificacy Traits. Number of lambs born and number of lambs weaned were reported for the period 1974 to 1996. Data were from ewes lambing.

Weight Traits. Birth weights (kilograms) were from lambs that survived to weaning to remove effects of still-born and immature lambs at birth. Average daily

Table 2. Summary of unadjusted means and standard deviations by breed

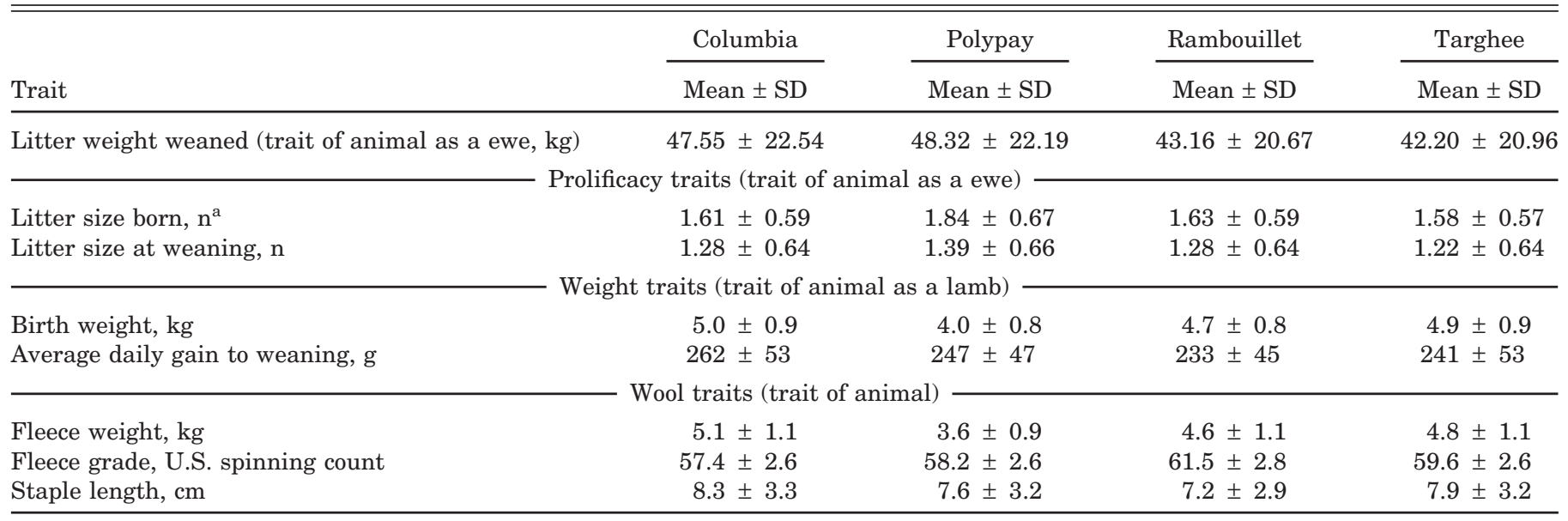

${ }^{\text {a} N u m b e r ~ o f ~ l a m b s ~ b o r n ~ p e r ~ e w e ~ l a m b i n g . ~}$ 
gain (grams per day) was calculated as the difference in weight between weaning and birth, divided by age in days at weaning. Individual weaning weights (kilograms) were adjusted to $120 \mathrm{~d}$ of age, using individual birth weight and average daily gain from birth to weaning. Weaning weight and preweaning average daily gain were nearly perfectly correlated (Bromley et al., 2000). Therefore, correlation analyses with litter weight weaned were done with average daily gain.

Litter Weight Weaned. Litter weight weaned per ewe lambing was the sum of naturally reared individual lamb weights for each year and is a trait of the ewe in contrast to birth weight and average daily gain, which are traits of the lamb.

Wool Traits. All sheep over 8 mo of age were sheared in late May. Fleeces with belly and face wool removed were weighed (kilograms). Staple length was measured before shearing (centimeters) at mid-side without stretching the fiber. Before 1990, three staple length measures were taken at mid-side by different individuals and averaged. Since 1990, only one mid-side measurement was taken. Fleeces were visually graded, sorted, and bagged by quality grade. Fleece grade was assigned immediately after shearing and expressed as a visual estimate of the USDA spinning count grade.

\section{Statistical Analysis}

All analyses were done separately for each breed. Descriptions of fixed and random effects in models for the traits are given in Table 3. Models for prolificacy, weight, and wool traits were the same as those described by Bromley et al. (2000). Mating sire was included only for litter weight at weaning because the genotype of the mating sire can influence weight at weaning. Birth weight and average daily gain to weaning were the only traits modeled with maternal genetic and permanent environmental effects (Bromley et al., 2000).

Single-Trait Analysis for Litter Weight Weaned. The vector of fixed effects included age of ewe at lambing, year of lambing, and type of foster code. If a ewe raised only her own lambs, the type of foster code was 1 . If a ewe fostered a lamb in addition to raising her own lamb, the type of foster code was 2. Foster lambs were grafted only to ewes that gave birth to single lambs. Only lambs reared by their birth dam were included in litter weight weaned for a ewe.

Bivariate Analyses. Pairs of traits were analyzed separately for each breed to estimate covariance components between litter weight weaned and prolificacy, growth, and wool traits. All bivariate analyses included a covariance between additive genetic effects of the two traits, plus additional covariances depending on the model for the traits (Table 3). Correlations between permanent environmental effects were estimated for litter weight weaned and prolificacy traits and for litter weight weaned and fleece traits recorded in the same year of production.

To account for correlations among environmental effects for litter weight weaned of the ewe and birth weight and average daily gain measured earlier in life, a permanent environmental effect was included in the model for those growth traits. This assignment of a permanent environmental effect to growth traits, which were measured only once for each animal, was done to force the covariance between environmental effects into the covariance between permanent environmental effects rather than to the covariance between residual effects when one of the traits was measured more than once. Although the environmental covariance across traits can be forced into the permanent environmental effects, interpretation requires some caution when one trait, such as birth weight, cannot have repeated mea-

Table 3. Description of fixed and random effects in models associated with each trait

\begin{tabular}{lll}
\hline \hline Trait & \multicolumn{1}{c}{ Fixed effect } & Random effect \\
\hline Litter size at birth & Age of ewe (year) & Direct genetic (ewe) \\
& Year of reproduction & Permanent environmental (ewe) \\
Litter size at weaning & Age of ewe (year) & Direct genetic (ewe) \\
& Year of reproduction & Permanent environmental (ewe) \\
& Foster code & Direct genetic (animal) \\
Birth weight (kg) and average & Sex of animal & Maternal genetic (dam) \\
daily gain to weaning, $g$ & Age of dam (year) & Permanent environment (dam) \\
& Birth year & \\
& Type of birth or rearing code & Direct genetic (animal) \\
Fleece weight, kg & Age of ewe, year and sex combination & Permanent environmental (animal) \\
Fleece grade (score) and & Day of year shorn & Direct genetic (animal) \\
staple length, $\mathrm{cm}$ & Age of ewe, year and sex combination & Direct genetic (ewe) \\
Litter weight weaned, $\mathrm{kg}$ & Day of year shorn & Permanent environmental (ewe) \\
& Age of ewe & Mating sire \\
\hline
\end{tabular}


Table 4. Estimates of variance components and genetic parameters ${ }^{\mathrm{a}}$ for Columbia, Polypay, Rambouillet, and Targhee breeds for litter weight weaned (kilograms) from single-trait analyses

\begin{tabular}{lcccccccc}
\hline \hline Breed & $\sigma_{\mathrm{a}}^{2}$ & $\sigma_{\text {pe(ewe) }}^{2}$ & $\sigma_{\mathrm{m} . \text { sire }}^{2}$ & $\sigma_{\mathrm{e}}^{2}$ & $\sigma_{\mathrm{p}}^{2}$ & $\mathrm{~h}^{2}$ & $\mathrm{pe}^{2}$ & $\mathrm{~ms}^{2}$ \\
\hline Columbia & 8.8 & 40.3 & 0.0 & 365.7 & 414.8 & 0.02 & 0.10 & 0.00 \\
Polypay & 37.1 & 0.2 & 11.2 & 337.4 & 385.9 & 0.10 & 0.00 & 0.03 \\
Rambouillet & 36.4 & 17.9 & 3.1 & 284.5 & 341.9 & 0.11 & 0.05 & 0.01 \\
Targhee & 20.9 & 18.2 & 0.1 & 232.9 & 272.1 & 0.08 & 0.07 & 0.00 \\
\hline
\end{tabular}

${ }^{\mathrm{a}} \sigma_{\mathrm{a}}^{2}=$ genetic variance; $\sigma_{\text {pe(ewe) }}^{2}=$ permament environmental variance due to the effects of the ewes; $\sigma_{\mathrm{m} . \text { sire }}^{2}=$ variance due to the effects of mating sires; $\sigma_{\mathrm{e}}^{2}=$ residual variance; $\sigma_{\mathrm{p}}^{2}=$ phenotypic variance; $\mathrm{h}^{2}=$ heritability estimate; $\mathrm{pe}^{2}=$ variance of permanent environmental effects of the ewe as fraction of total variance; $\mathrm{ms}^{2}=$ variance of effects of mating sire as fraction of total variance.

sures (Okut et al., 1999). Because of the complete confounding between the permanent environmental and residual effects, variance due to those effects can go to either component of variance, which also makes interpretation of the correlations among permanent environmental effects difficult.

One way to interpret the residual and permanent environmental variances and covariances is to calculate a combined environmental variance from the sum of the original residual and permanent environmental variance components, which can be used to calculate an environmental correlation as in the following formula:

$$
\mathrm{r}_{\mathrm{e}_{\mathrm{sm}}}=\left[\mathrm{r}_{\mathrm{pe}}\left(\mathrm{pe}_{\mathrm{s}}^{2} \times \mathrm{pe}_{\mathrm{m}}^{2}\right)^{0.5}\right] /\left[\left(\mathrm{pe}_{\mathrm{s}}^{2}+\mathrm{e}_{\mathrm{s}}^{2}\right)\left(\mathrm{pe}_{\mathrm{m}}^{2}+\mathrm{e}_{\mathrm{m}}^{2}\right)^{0.5}\right.
$$

where $r_{\mathrm{pe}_{\mathrm{sm}}}$ is the correlation between permanent environmental effects, $\mathrm{pe}_{\mathrm{s}}^{2}$ and $\mathrm{pe}_{\mathrm{m}}^{2}$ are fractions of variance due to permanent environmental effects, and $\mathrm{e}_{\mathrm{s}}^{2}$ and $\mathrm{e}_{\mathrm{m}}^{2}$ are fractions of variance due to residual effects for traits s and m (Okut et al., 1999).

Covariances between temporary environmental effects were estimated from bivariate analyses for litter weight weaned and each prolificacy trait because observations for litter weight weaned and the two prolificacy traits were available in the same years for each ewe.

All analyses were conducted using a derivative-free REML algorithm (Graser et al., 1987) implemented in computer programs of Boldman et al. (1993). Restarts at local convergence (variance of the -2 log likelihoods in the simplex of less than $10^{-6}$ ) were done until global convergence was declared when the -2 log likelihoods did not change to the third decimal.

\section{Results and Discussion}

\section{Litter Weight Weaned}

Estimates of variance components from single-trait analyses for the four breeds for litter weight weaned are given in Table 4 . Heritability estimates ranged from 0.02 to 0.11 . The review by Fogarty (1995) lists an average estimate of heritability of 0.14 and of repeatability of 0.15 from six and four studies, respectively. The aver- age estimate for the heritability for the four breeds reported here was less, 0.08 , but the average estimate of repeatability was similar, 0.13 . The low heritability estimates for this trait are not surprising because litter weight weaned is a complex composite trait. Genetic improvement in litter weight weaned has been previously attributed to fertility, prolificacy, lamb growth, lamb survival to weaning, and ewe viability from breeding to weaning (Ercanbrack and Knight, 1998). Environmental effects have a highly significant effect on the expression of litter weight weaned as evidenced by the large residual variances. Estimates of relative variance due to permanent environmental effects associated with the ewe were not large, ranging from 0.00 to 0.10 . Thus, a ewe's lifetime expression of litter weight weaned would not be significantly influenced by permanent environmental effects linked with the ewe under this management system.

Because litter weight weaned is a composite trait, comparison of its heritability estimate with estimates for the major component traits, such as individual lamb weaning weight and litter size weaned, is warranted. Heritability estimates for litter weight weaned were less than previously reported heritability estimates for individual lamb weaning weight. Van Zyl (1998) reported heritability estimates for individual lamb weaning weights at $120 \mathrm{~d}$ of age ranging from 0.09 to 0.20 based on the same data. Al-Shorepy and Notter (1996) reported a similar direct heritability estimate of 0.19 for weaning weight at $120 \mathrm{~d}$ of age. Maria et al. (1993), using an animal model, obtained heritability estimates for individual weaning weights at $90 \mathrm{~d}$ and $120 \mathrm{~d}$ of age of 0.04 to 0.34 and 0.05 to 0.41 , respectively. Tosh and Kemp (1994) reported direct and maternal heritabilities for weaning weight at $100 \mathrm{~d}$ that ranged from 0.14 to 0.39 and 0.02 to 0.19 , respectively. Litter weight weaned and individual lamb weight are not the same trait unless the population has only single reared lambs. Selection for individual lamb weaning weight can improve lamb growth but would not necessarily increase and could decrease total lamb production per ewe (Lasslo et al., 1985; Snowder et al., 1996).

Heritability estimates for litter weight weaned, although small, were greater than the estimates for the 
component trait, litter size at weaning, for all breeds except for the Columbia breed, for which the estimates were the same (Bromley et al., 2000). Direct selection for litter weight weaned may be more appropriate than direct selection for litter size. In a selection experiment with mice, direct selection for litter weight weaned was three times as effective as selection for litter size at birth for increasing litter weight weaned (Luxford and Beilharz, 1990).

Effects of mating sires on litter weight weaned were small, as estimates of fractional variance ranged from 0.00 to 0.03 and averaged 0.01 of the phenotypic variance. Mating sire effects would primarily be associated with the lamb weight component of litter weight and with lamb survival.

\section{Litter Weight Weaned and Prolificacy Traits}

Estimates of genetic parameters from bivariate analyses for litter weight weaned paired with litter size at birth and weaning are reported in Table 5. Heritability estimates for litter size at birth from the bivariate analyses were similar to the estimates from single-trait analyses (Bromley et al., 2000) for all breeds. Heritability estimates for litter weight weaned in the bivariate analyses with litter size at birth were similar to the heritability estimates for litter weight weaned in the single-trait analyses for all breeds. Estimates of direct genetic correlations between litter weight weaned and litter size at birth were positive and moderate, ranging from 0.42 to 0.65 , which are similar to the average of estimates reported by Fogarty (1995). These results suggest that selection to increase either litter weight weaned or litter size at birth would result in a moderate positive response for the other trait.
For the two-trait analyses with litter size at weaning, estimates of heritability for litter weight weaned were the same as when analyzed with litter size born and were similar to those from the single-trait analyses. Heritability estimates for litter size at weaning derived from bivariate analyses were similar to the estimates from the single-trait analyses for Columbia and Rambouillet breeds; however, heritability estimates from bivariate analyses were slightly larger than estimates from the single-trait analyses for Polypay and Targhee breeds (Bromley et al., 2000).

Estimates of genetic correlations between litter weight weaned and litter size at weaning were positive and high, ranging from 0.80 to 0.99 (Table 5), somewhat larger on average than estimates summarized by Fogarty (1995). Therefore, direct selection for either the composite trait (litter weight weaned) or the component trait (litter size at weaning) could be expected to improve ewe productivity in contrast to the experimental results with mice (Luxford and Beilharz, 1990). For commercial and some purebred producers, counting lambs within a litter at weaning may be more practical than weighing individual lambs.

Estimates of correlations between permanent environmental effects of ewes were large and negative for litter weight weaned and litter size at birth $(-1.00$ to -0.65 except for Columbia with $r_{p}=0.14$ ), but large and positive (0.89 to 1.00) for litter weight weaned and litter size at weaning. The high estimates of correlations for permanent environmental effects of ewes may be due to generally small estimates of variance due to permanent environmental effects of ewes especially for litter size at birth.

Estimates of correlations between residual effects for litter weight weaned and litter size at birth were moder-

Table 5. Estimates of genetic parameters for litter weight weaned and prolificacy traits from bivariate analyses by breed ${ }^{a}$

\begin{tabular}{|c|c|c|c|c|c|c|c|c|}
\hline \multirow{2}{*}{$\begin{array}{l}\text { Prolificacy Trait: } \\
\text { Parameters }^{\mathrm{b}}\end{array}$} & \multicolumn{4}{|c|}{ Litter size at birth } & \multicolumn{4}{|c|}{ Litter size at weaning } \\
\hline & COLU & POLY & RAMB & TARG & COLU & POLY & RAMB & TARG \\
\hline$r_{g}$ & 0.65 & 0.42 & 0.62 & 0.55 & 0.80 & 0.90 & 0.99 & 0.91 \\
\hline $\mathrm{h}_{1}^{2}$ & 0.02 & 0.07 & 0.10 & 0.10 & 0.02 & 0.07 & 0.10 & 0.10 \\
\hline $\mathrm{h}_{2}^{2}$ & 0.07 & 0.12 & 0.09 & 0.10 & 0.03 & 0.04 & 0.05 & 0.07 \\
\hline$r_{p}$ & 0.14 & -0.81 & -0.65 & -1.00 & 0.96 & 1.00 & 0.89 & 0.94 \\
\hline $\mathrm{p}_{1}^{2}$ & 0.10 & 0.04 & 0.05 & 0.03 & 0.08 & 0.06 & 0.04 & 0.04 \\
\hline $\mathrm{p}_{2}^{2}$ & 0.02 & 0.01 & 0.03 & 0.02 & 0.05 & 0.04 & 0.03 & 0.02 \\
\hline $\mathrm{ms}_{1}^{2}$ & 0.00 & 0.02 & 0.01 & 0.00 & 0.00 & 0.01 & 0.00 & 0.00 \\
\hline$r_{e}$ & 0.41 & 0.33 & 0.36 & 0.36 & 0.95 & 0.94 & 0.95 & 0.95 \\
\hline $\mathrm{e}_{1}^{2}$ & 0.88 & 0.86 & 0.84 & 0.86 & 0.89 & 0.86 & 0.85 & 0.86 \\
\hline $\mathrm{e}_{2}^{2}$ & 0.91 & 0.87 & 0.88 & 0.88 & 0.92 & 0.92 & 0.92 & 0.92 \\
\hline$\sigma_{1}^{2}$ & 417 & 385 & 342 & 372 & 419 & 383 & 347 & 370 \\
\hline$\sigma_{2}^{2}$ & 0.30 & 0.37 & 0.27 & 0.27 & 0.36 & 0.35 & 0.34 & 0.36 \\
\hline
\end{tabular}

${ }^{\mathrm{a}}$ COLU, Columbia; POLY, Polypay; RAMB, Rambouillet; TARG, Targhee.

${ }^{b} r_{g}$, genetic correlation; $h_{i}^{2}$, heritability trait $i ; r_{p}$, correlation between permanent environmental effects of ewe; $\mathrm{p}_{i}^{2}$, fraction of variance due to permament environmental effects of ewe; $\mathrm{ms}_{1}^{2}$, fraction of variance due to mating sire effect for LWW; $r_{e}$, residual correlation, $e_{i}^{2}$, fraction of variance due to residual effects; $\sigma_{\mathrm{i}}^{2}$, phenotypic variance. 
Table 6. Estimates of genetic parameters for litter weight weaned (trait 1) with birth weight and with average daily gain from bivariate analyses by breed ${ }^{\mathrm{b}}$

\begin{tabular}{|c|c|c|c|c|c|c|c|c|}
\hline \multirow[b]{2}{*}{ Parameter $^{b}$} & \multicolumn{4}{|c|}{ Birth weight, kg } & \multicolumn{4}{|c|}{ Average daily gain, $\mathrm{kg} / \mathrm{d}$} \\
\hline & COLU & POLY & RAMB & TARG & COLU & POLY & RAMB & TARG \\
\hline$r_{\mathrm{g}}$ & -0.22 & 0.28 & 0.23 & 0.11 & 0.07 & 0.23 & -0.07 & 0.05 \\
\hline $\mathrm{h}_{1}^{2}$ & 0.03 & 0.09 & 0.14 & 0.11 & 0.11 & 0.07 & 0.21 & 0.19 \\
\hline $\mathrm{h}_{2}^{2}$ & 0.25 & 0.16 & 0.20 & 0.25 & 0.06 & 0.17 & 0.13 & 0.24 \\
\hline $\mathrm{m}_{2}^{2}$ & 0.28 & 0.21 & 0.23 & 0.20 & 0.13 & 0.08 & 0.26 & 0.19 \\
\hline $\mathrm{r}_{\mathrm{a} 2 \mathrm{~m} 2}$ & -0.14 & 0.33 & 0.07 & 0.20 & 0.00 & -0.11 & -0.33 & -0.28 \\
\hline $\mathrm{r}_{\mathrm{a} 1 \mathrm{~m} 2}$ & 0.70 & 0.71 & 0.43 & 0.35 & 1.00 & 0.94 & 0.97 & 0.95 \\
\hline $\mathrm{p}_{1}^{2}$ & 0.08 & 0.03 & 0.02 & 0.02 & 0.02 & 0.02 & 0.00 & 0.00 \\
\hline $\mathrm{p}_{2}^{2}$ & 0.04 & 0.08 & 0.51 & 0.31 & 0.20 & 0.10 & 0.18 & 0.05 \\
\hline $\mathrm{ms}_{1}^{2}$ & 0.00 & 0.03 & 0.01 & 0.00 & 0.00 & 0.03 & 0.01 & 0.00 \\
\hline $\mathrm{d}_{2}^{2}$ & 0.04 & 0.08 & 0.06 & 0.08 & 0.01 & 0.02 & 0.00 & 0.01 \\
\hline $\mathrm{r}_{\mathrm{e}}$ & -0.02 & 0.00 & -0.03 & -0.02 & -0.01 & 0.00 & 0.00 & 0.00 \\
\hline $\mathrm{e}_{1}^{2}$ & 0.88 & 0.85 & 0.83 & 0.86 & 0.87 & 0.88 & 0.79 & 0.81 \\
\hline $\mathrm{e}_{2}^{2}$ & 0.42 & 0.41 & 0.00 & 0.12 & 0.60 & 0.65 & 0.49 & 0.56 \\
\hline$\sigma_{1}^{2}$ & 416 & 387 & 344 & 372 & 421 & 379 & 358 & 385 \\
\hline$\sigma_{2}^{2}$ & 0.59 & 0.43 & 0.42 & 0.53 & 1,790 & 1,445 & 1,419 & 1,927 \\
\hline
\end{tabular}

${ }^{\mathrm{a} C O L U}$, Columbia; POLY, Polypay; RAMB, Rambouillet; TARG, Targhee.

${ }^{b} r_{g}$, direct genetic correlation, $h_{i}^{2}$, direct heritability trait $i ; m_{2}^{2}$, maternal heritability for trait $2 ; r_{a 2 m 2}$, direct maternal genetic correlation for trait $2 ; \mathrm{r}_{\mathrm{a} 1 \mathrm{~m} 2}$, direct genetic for trait 1 and maternal genetic for trait 2 ; $\mathrm{p}_{\mathrm{i}}^{2}$, fraction of variance due to direct permanent environmental effects; $\mathrm{ms}_{1}^{2}$, fraction of variance due to mating sire effects for LWW; $d_{2}^{2}$, fraction of variance due to maternal permanent environmental effects for trait $2 ; \mathrm{e}_{\mathrm{i}}^{2}$, fraction of variance due to residual effects; $\sigma_{\mathrm{i}}^{2}$, phenotypic variance; $\mathrm{r}_{\mathrm{e}}$, total environmental correlation.

ate and positive ( 0.33 to 0.41 ), but were large and positive $(0.94$ to 0.95$)$ for litter weight weaned and litter size at weaning. Because litter size at weaning is a multiplicative component of litter weight weaned, large estimates of correlation between the temporary environmental effects were expected, as litter size is a major component of litter weight weaned.

\section{Litter Weight Weaned and Growth Traits}

Estimates of genetic and environmental parameters from bivariate analyses for litter weight weaned with birth weight and preweaning average daily gain are reported in Table 6. Heritability estimates for birth weight in two-trait analyses, compared with the heritability estimates for birth weight in single-trait analyses (Bromley et al., 2000), were somewhat larger for Columbia, Rambouillet, and Targhee breeds but were the same for Polypay. Estimates of direct genetic correlations between litter weight weaned and birth weight ranged from -0.22 to 0.28 (Table 6). The average of estimates of genetic correlations (0.10) between direct genetic effects for litter weight weaned and birth weight suggests that a small positive genetic correlation exists. Selection to improve genetic merit in either of these two traits would have little influence on genetic response in the other trait. Estimates of correlation between direct genetic values for litter weight weaned and maternal genetic values for birth weight were positive and ranged from moderate for Rambouillet and Targhee ( 0.43 and
0.35) to large (0.70 and 0.71) for Columbia and Polypay breeds. Such positive correlations would be expected because birth weight is a component of litter weight weaned of the ewe and a positive maternal effect on individual lamb birth weight would be expressed in litter weight weaned as a trait of the ewe. Selection to improve litter weight weaned on a ewe would, as might be expected, also tend to increase maternal genetic value for birth weight.

Estimates of direct genetic correlations between litter weight weaned and preweaning average daily gain were relatively small and ranged from -0.07 and 0.23 (Table 6). Litter weight weaned is a composite trait of litter size and average weaning weight of lambs in the litter. The small genetic correlation with average daily gain indicates that the main component of litter weight weaned is litter size. Therefore, selection to increase litter weight weaned would have little influence on average daily gain or selection on average daily gain would have little correlated response in litter weight weaned. The correlations between maternal genetic value for average daily gain to weaning and direct genetic value for litter weight weaned were all greater than 0.90 , averaging 0.97 . Such high correlations would be expected because a lamb's growth rate is an expression of the ewe's maternal ability as well as her transmitting ability for growth and litter size weaned in a maternally measured trait. Heritability estimates for average daily gain in two-trait analyses compared with heritability estimates for average daily gain in single-trait analyses 
(Bromley et al., 2000) were slightly smaller for Columbia and Polypay breeds, but somewhat larger for Rambouillet and Targhee breeds. Generally positive genetic correlations between litter weight weaned and litter size at birth, litter size at weaning, and average daily gain were inferred from the positive phenotypic responses in those traits during long-term selection for litter weight weaned (Ercanbrack and Knight, 1998). Fogarty (1995) did not report any estimates of genetic correlations between birth or weaning weight and litter weight weaned.

For bivariate analyses of litter weight weaned and average daily gain, estimates of variance due to permanent environmental effects of ewes on litter weight weaned as proportions of total variance were small or near zero for all breeds and estimates of variance due to mating sires as proportions of total variance were near zero except for Polypay. Total environmental correlations were near zero for bivariate analyses of litter weight weaned with birth weight or average daily gain.

\section{Litter Weight Weaned and Wool Traits}

Estimates of genetic parameters from bivariate analyses for litter weight weaned with different combinations of wool traits are reported in Table 7. Heritability estimates for litter weight weaned were similar for single- and two-trait analyses with wool traits. In the twotrait analyses, the heritability estimates for litter weight weaned were the same for all four breeds when paired with any of the three wool traits.

Estimates of direct genetic correlations between litter weight weaned and all three wool traits were on average near zero (Table 7 ), except for the -0.56 for Columbia between litter weight weaned and fleece weight, which may be an artifact associated with the small heritability for litter weight weaned for Columbia. Fogarty (1995) reported only one estimate of the genetic correlation between litter weight weaned and any wool traits $(0.63$ with greasy fleece weight). The average of the correlations suggests that litter weight weaned and these wool traits are genetically independent. Thus, selection to improve litter weight weaned or any of these wool traits would not likely result in much correlated genetic response for the other trait.

Estimates of correlations for permanent environmental effects of ewes for litter weight weaned and fleece weight varied from -0.68 to 0.21 . The large negative correlations for permanent environmental effects between litter weight weaned and staple length may be due to the small number of repeated measurements on staple length and have little importance due to the nearzero amount of variance in staple length accounted for by permanent environmental effects.

\section{Implications}

Litter weight weaned per ewe lambing has been proposed as a measure of ewe productivity. Few estimates

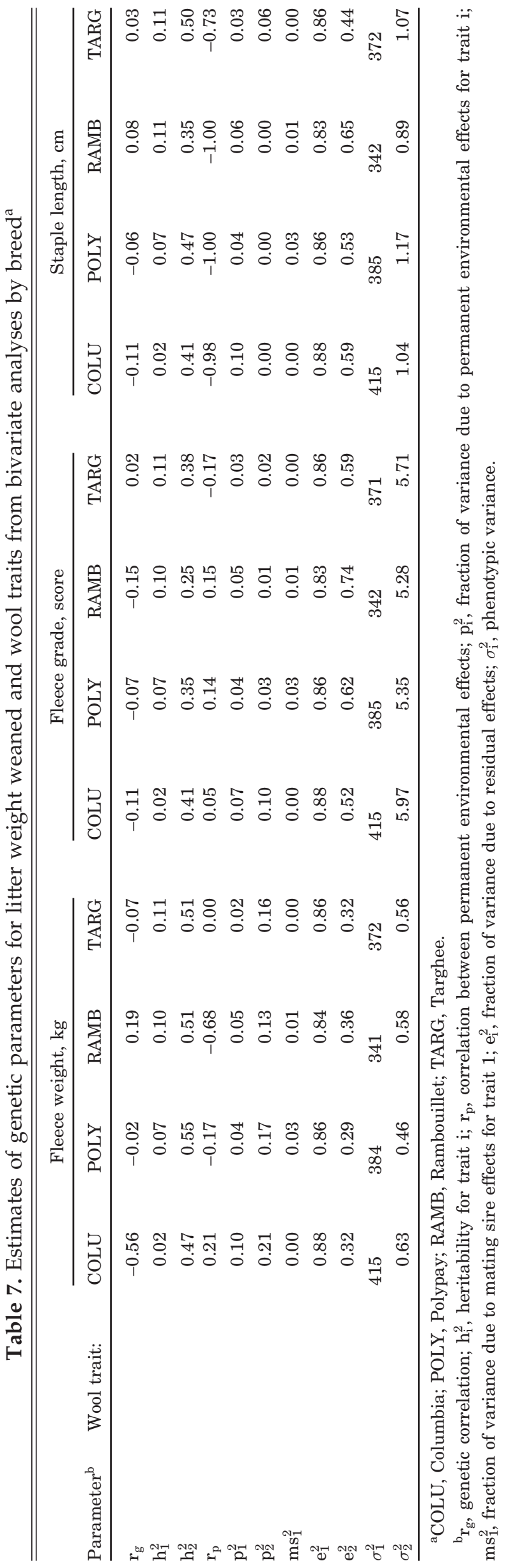


of genetic correlations between litter weight weaned and prolificacy, growth, or wool traits have been previously reported. This study shows that litter weight weaned has a relatively low direct heritability, but that response to selection could be significant due to the relatively large genetic variance. The estimates of moderate and positive genetic correlations of litter weight weaned with litter size at birth, litter size at weaning, birth weight, and preweaning average daily gain suggest that positive genetic change would be made in many traits by selecting for litter weight weaned. Selection for litter weight weaned should result in little change in wool traits because wool traits are essentially genetically uncorrelated with litter weight weaned. These estimates of genetic correlations and heritabilities can be used to calculate expected responses in the other traits if selection is on litter weight weaned, or can be used to develop selection indexes to predict ewe productivity.

\section{Literature Cited}

Al-Shorepy, S. A., and D. R. Notter. 1996. Genetic variation for ewe reproduction, lamb growth, and lamb scrotal circumference in a fall-lambing sheep flock. J. Anim. Sci. 74:1490-1498.

Boldman, K. G., L. A. Kriese, S. D. Kachman, and L. D. Van Vleck. 1993. A manual for the use of MTDFREML. USDA, ARS, Clay Center, NE.

Bromley, C. M., G. D. Snowder, and L. D. Van Vleck. 2000. Genetic parameters among weight, prolificacy, and wool traits of Colum- bia, Polypay, Rambouillet, and Targhee sheep. J. Anim. Sci. 78:846-858.

Ercanbrack, S. K., and A. D. Knight. 1998. Responses to various selection protocols for lamb production in Rambouillet, Targhee, Columbia, and Polypay sheep. J. Anim. Sci. 76:1311-1325.

Fogarty, N. M. 1995. Genetic parameters for live weight, fat and muscle measurements, wool production and reproduction in sheep: A review. Anim. Breed. Abstr. 64:101-143.

Graser, H-U., S. P. Smith, and B. Tier. 1987. A derivative-free approach for estimating variance components in animal models by restricted maximum likelihood. J. Anim. Sci. 64:1362-1370.

Lasslo, L. L., G. E. Bradford, D. T. Torrell, and B. W. Kennedy. 1985. Selection for weaning weight in Targhee sheep in two environments. I. Direct response. J. Anim. Sci. 61:376-386.

Luxford, B. G., and R. G. Beilharz. 1990. Selection response for litter size at birth and litter weight at weaning in the first parity in mice. Theor. App. Genet. 80:625-630.

Maria, G. A., K. G. Boldman, and L. D. Van Vleck. 1993. Estimates of variances due to direct and maternal effects for growth traits of Romanov sheep. J. Anim. Sci. 71:845-849.

Okut, H., C. M. Bromley, L. D. Van Vleck, and G. D. Snowder. 1999. Genotypic expression at different ages: I. Prolificacy traits of sheep. J. Anim. Sci. 77:2357-2365.

Snowder, G. D., P. G. Hatfield, and A. D. Knight. 1996. Composite trait selection for lamb production. In: Proc. National Sheep Genetics Symposium, Columbus, OH. American Sheep Industry Association, Engelwood, CO. pp 137-144.

Tosh, J. J., and R. A. Kemp. 1994. Estimation of variance components for lamb weights in three sheep populations. J. Anim. Sci. 72:1184-1190.

van Zyl, C. M. 1998. Estimation of genetic parameters for production traits of corn and dual purpose sheep. Ph.D. dissertation. University of Nebraska, Lincoln. 